\title{
MIGRACIJE V SLOVENSKIH ŠOLSKIH GEOGRAFSKIH UČBENIKIH
}

\author{
dr. Jurij Senegačnik \\ Modrijan založba, d. o. o., Poljanska cesta I5, SI-I000 Ljubljana \\ e-mail: jure@modrijan.si
}

\section{Pregledni znanstveni članek}

COBISS 1.02

DOI: $10.4312 /$ dela.40.10.179-195

\section{Izvleček}

V Sloveniji se migracije obravnavajo v skoraj vseh geografskih učbenikih za različne stopnje izobraževanja. V učbenikih za osnovno šolo od šestega do devetega razreda učenci pridobivajo znanje o migracijah po induktivni poti. Zahtevnost obravnave in količina informacij se s starostno stopnjo stopnjujeta. V gimnazijskem programu je učna pot pridobivanja znanja o migracijah deduktivna. Največ pozornosti je migracijam namenjeno v učbenikih obče geografije. V učbenikih za negimnazijske programe se migracije obravnavajo $\mathrm{v}$ manjši meri, pristopi pa niso enotni.

Ključne besede: migracije, demografija, geografija prebivalstva, geografski učbenik, didaktika geografije

\section{MIGRATIONS IN SLOVENIAN GEOGRAPHYTEXTBOOKS}

\begin{abstract}
In Slovenia, the migrations are treated in almost all geographical textbooks for different levels of education. In the textbooks for the elementary school from the sixth to ninth grade, students acquire knowledge of the migrations by the inductive approach. Difficulty level of treatment and quantity of information are increasing by the age level. In the grammar school program a trail of gaining knowledge on migration is deductive. Most attention is dedicated to migrations in general geography textbooks. The textbooks for vocational and technical school programs deal with migrations to a lesser extent and with different approaches.
\end{abstract}

Key words: migrations, demography, population geography, geography textbook, didactics of geography 


\section{UVOD}

Migracije so v slovenski geografiji dokaj raziskana tematika, zato ne preseneča, da so učne vsebine s tega področja predstavljene tudi v šolskih geografskih učbenikih. To problematiko sicer najdemo tudi v učbenikih za zgodovino in nekatere druge družboslovne predmete, vendar je obseg njene obravnave v geografskih učbenikih tolikšen, da si zasluži posebno obravnavo. Pri raziskavi učbenikov smo se omejili le na prikaz migracij, ne pa tudi sorodnih pojmov (poselitve, naselitve ipd.), ki so sicer z migracijami vsaj posredno povezani. Vključitev teh dodatnih pojmov v raziskavo bi po nepotrebnem razširila obseg že tako obširnega prispevka. Kakšnega od teh pojmov bomo omenili le pri razčlenjevanju migracij v učnih načrtih za geografijo, saj učbeniki pogosto obravnavajo več učnih vsebin, kot bi lahko sklepali na osnovi ciljev, opredeljenih v učnih načrtih.

Slovenske raziskave s področja geografskih učbenikov so precej redke. Še posebej malo je prispevkov, ki prinašajo rezultate raziskovanja zastopanosti učnih vsebin o določeni specifični tematiki v učbenikih (Senegačnik, 2007; 2008; 2012b).

V raziskavo smo vključili vse geografske učbenike za osnovno šolo, gimnazijski program in srednje tehniško oziroma strokovno ter poklicno tehniško izobraževanje, ki so navedeni v katalogih veljavnih učbenikov na spletni aplikaciji Trubar (Ministrstvo RS za šolstvo in šport). S tem smo jasno postavili razmejitev do nekaterih učbenikov, ki se v šolah ne uporabljajo več. Prav tako nismo obravnavali nekaterih učbenikov, ki so sicer uradno še veljavni, vendar so založbe v času od leta 2008 dalje, ko se je zaključila zadnja kurikularna prenova, zanje že pripravile nove prenovljene izdaje, ki imajo včasih tudi nekoliko spremenjen naslov.

Namen raziskave je bil ugotoviti, v kolikšni meri so v izbranih geografskih učbenikih zastopane učne vsebine s področja migracij, na čem je poudarek pri obravnavi migracij in kakšne so razlike v načinih prikaza teh vsebin v učbenikih za različne starostne stopnje in vrste izobraževanja. Pri raziskavi smo uporabili deskriptivno metodo in posebno metodo dela s pedagoško dokumentacijo, med katero sodijo tudi učbeniki. Takšno metodo lahko po Muževiću (1973, str. 179) opredelimo kot komparativno analizo učbenikov. Good in Scates (1967, str. 533) v zvezi s tem govorita o kvantitativni analizi dokumentarnega gradiva. Omenjene metode dela so sicer že nekoliko starejše, vendar jih v novejšem času ni nadomestila nobena novejša in učinkovitejša metoda.

\section{MIGRACIJEV UČNIH NAČRTIH ZA GEOGRAFIJO}

Pred analizo prikaza migracij v geografskih učbenikih, si moramo ogledati, kaj je o tem predvideno v učnih načrtih. Slednji so namreč zavezujoči dokumenti, neke vrste 'ustava' oziroma 'zakoni', ki jih morajo učitelji obvezno in dosledno upoštevati ter jim slediti pri delu v razredu. Učbeniki so namreč le učila oziroma učna sredstva, ki jih učitelji (lahko) uporabljajo ali pa tudi ne. Tako je zamišljeno v splošnodidaktični teoriji, praksa pa kaže precej drugačno, čeprav ne povsem enovito podobo. Učitelji učne načrte sicer poznajo in jim sledijo, vendar so v praksi učbeniki tisti, ki veliko bolj določajo delo v razredu, čeprav ni v nobenem dokumentu izrecno zapisano, da so 
učitelji učbenike sploh dolžni uporabljati. Kljub temu da skoraj ni učitelja, ki pri pouku geografije ne bi uporabljal učbenikov, pa je njihova uporaba pri učencih manj pogosta, kot bi pričakovali. V zadnjih letih je moč tudi v Sloveniji zaslediti močan porast ponudbe različnih e-gradiv s področja geografije, v bodoče naj bi dobili celo 'prave' e-učbenike s tega področja. V sedanji praksi e-gradiva kolikor toliko redno uporablja le majhen delež učiteljev, zato lahko rečemo, da njihova uporaba praviloma ne zmanjšuje dejanskega uporabnega pomena učbenikov. Prav tako e-gradiva nimajo posebnega vpliva na to, da bi se učitelji zaradi njih bolj naslonili na učni načrt in manj na učbenike. Iz tega sledi, da je nek pojav, na primer migracije, veliko bolj smiselno analizirati v učbenikih kot pa v učnih načrtih ali različnih e-gradivih. Ker pa so učni načrti zavezujoč dokument, na osnovi katerega nastanejo učbeniki, moramo najprej opraviti tudi kratko analizo pojavljanja pojma migracij v učnih načrtih.

Veljavni učni načrt za geografijo v osnovni šoli (Kolnik in sod., 2011) pojma 'migracije' (s tujko) sploh nikjer ne navaja. Na enem samem mestu, in sicer šele v (manj pomembnih) didaktičnih priporočilih na koncu, je enkrat omenjen pojem 'selitve ljudstev', in sicer v zvezi s povezovanjem pouka geografije in zgodovine. V osnovnošolskem učnem načrtu se na 11 mestih omenja pojem 'poselitev'. Pojav je sicer lahko tesno povezan z migracijami, vendar se v učnem načrtu praviloma navaja v kontekstu, ki ne vključuje tudi obvezne sočasne obravnave migracij.

Učni načrt za splošno, klasično in ekonomsko gimnazijo (Polšak in sod., 2008) v jedrnem poglavju o ciljih in vsebinah pojma 'migracije' in njegovih izpeljank (npr. 'migracijski tokovi') ne omenja pri obči geografiji, kamor bi najbolj sodili, ampak šele pri regionalni geografiji sveta in Evrope. Pojem 'migracije' se potem ponovno omenja v zadnjih dveh poglavjih, in sicer enkrat pri medpredmetnih povezavah in enkrat pri didaktičnih priporočilih. V tem učnem načrtu pa se omenja tudi pojem 'selitev'. Najpomembnejša je njegova omemba $v$ jedrnem poglavju o ciljih in vsebinah pri obči geografiji, pa tudi pri geografiji Slovenije, dvakrat je omenjen tudi v nadaljevanju v poglavjih o izbirnih vsebinah in medpredmetnih povezavah. Na več mestih (dvanajstkrat) se v učnem načrtu omenjata tudi pojma 'poselitev' in 'naselitev', in sicer povečini v jedrnem poglavju o ciljih in vsebinah.

Učni načrt za strokovno gimnazijo (Lipovšek in sod., 2008) navaja pojem migracij najprej v poglavju o splošnih ciljih in kompetencah (enkrat), v jedrnem poglavju o ciljih in vsebinah (enkrat), in sicer pri geografiji sveta, potem pa še v zadnjih dveh poglavjih o vrednotenju dosežkov (enkrat) ter ponudbi izbirnih sklopov (dvakrat). Pojem 'selitev' omenja le enkrat v jedrnem poglavju o ciljih in vsebinah, in sicer pri geografiji sveta. Poleg tega zasledimo še eno omembo pojma ‘poselitev' v poglavju o ponudbi izbirnih sklopov.

V učnem načrtu za srednje strokovno in srednje poklicno-tehniško izobraževanje (Besednjak in sod., 2007) sta pojma 'migracije' oziroma 'selitev' razumljivo še bolj skopo zastopana, saj je pomen geografije $\mathrm{v}$ teh srednješolskih programih bistveno manjši kot $\mathrm{v}$ gimnazijskem programu. Beseda 'migracije' se po enkrat omenja v poglavju o splošnih ciljih, v jedrnem poglavju o ciljih in vsebinah, v poglavju o vrednotenju dosežkov in $\mathrm{v}$ zadnjem poglavju o ponudbi izbirnih sklopov. Beseda 'selitve' se vsega skupaj omenja dvakrat, in sicer enkrat $\mathrm{v}$ jedrnem poglavju o ciljih in vsebinah ter enkrat $\mathrm{v}$ zadnjem 
poglavju o ponudbi izbirnih sklopov. Ker se v osnovnošolskih učbenikih migracije omenjajo in obravnavajo manjkrat kot $\mathrm{v}$ srednješolskih, in ker se učenci $\mathrm{v}$ teh učbenikih $\mathrm{z}$ njimi srečujejo prvič, bomo pojavljanje migracij v osnovnošolskih učbenikih razčlenili z nekaj več pojasnili kot v srednješolskih.

\section{MIGRACIJEV UČBENIKIH ZA OSNOVNO ŠOLO}

$\mathrm{V}$ šestem razredu je glavnina vseh učnih ciljev namenjena tistim temeljem obče geografije, ki tvorijo nekakšno trdno podstat, na katero lahko potem v višjih razredih osnovne šole naslonimo regionalnogeografsko obravnavo Evrope, neevropskih kontinentov in Slovenije. Sklop učnih vsebin v 6. razredu bi lahko imenovali 'mala obča geografija', vendar je pri tem treba opozoriti, da gre v veliki večini za učne cilje in vsebine s področja fizične in ne družbene geografije. Zato učbeniki za 6. razred tako rekoč ne omenjajo migracij. Manjša izjema je le učbenik Moja prva geografija (Senegačnik, 2013b), ki v poglavju o toplotnih pasovih omenja selilno poljedelstvo, požigalništvo ter selitve beduinov, vendar vsakič le z enim stavkom.

V sedmem razredu so učni cilji usmerjeni v usvajanje znanja s področja regionalne geografije Evrope in Azije, pri čemer se migracije v različnih učbenikih omenjajo bolj ali manj le v posameznih stavkih, vendar še zdaleč ne v vseh učbenikih pri istih vsebinskih sklopih. V učbeniku Geografija 7 (Račič, Tomšič, 2005) so v poglavju o gospodarski raznolikosti Južne in Jugovzhodne Evrope migracije (v obliki odseljevanja s podeželja v mesta) omenjene kot vzrok za opuščanje kulturnih teras v Sredozemlju, v poglavju o državah Jugozahodne Azije pa je pri nastanku države Izrael razloženo, da je nastala s priseljevanjem Judov iz drugih delov sveta. Učbenik Geografija 7 (Miklavc Pintarič, Popit, 2005) v poglavju o Vzhodni Evropi in Severni Aziji omenja prisilne migracije v Sibirijo, v poglavju o Vzhodni Aziji nomadizem in preseljevanjih mladih s podeželja v mesta, v poglavju o Jugozahodni Aziji pa naseljevanje Judov v novo nastalem Izraelu.

V učbeniku Raziskujem stari svet 7 (Verdev, 2010a) se z migracijami najprej srečamo v uvodnem tematskem sklopu o Evropi kot celoti, kjer je v zgodovinskem kontekstu omenjeno preseljevanje ljudstev. V poglavju o Zahodni Evropi je v posebni rubriki $V$ žarišču omenjeno, da se ljudje skupaj z gospodarstvom selijo iz notranjosti na obalo. V poglavju o Vzhodni Evropi in Severni Aziji je omenjeno priseljevanje ljudi v mesta ter odseljevanje v razvitejše države. Odseljevanje v mesta je ponovno omenjeno v poglavju o prebivalstvu Azije, migracije v obliki begunstva pa v zadnji rubriki Žarišče na koncu učbenika. V tem učbeniku se v poglavju o Zahodni Evrope pri obravnavi prebivalstva in gospodarstva prvič srečamo tudi z nekoliko obširnejšo obravnavo migracij v obliki priseljevanja. Ta prikaz je zelo pomemben, saj se ne omejuje le na omembo v enem stavku, ampak v dveh celih odstavkih razčlenjuje občutja priseljencev in razloge, zakaj je Zahodna Evropa za njih tako privlačna. Tu se prvič srečamo ne le z nekoliko bolj vzročno-posledično in hkrati problemsko obravnavo, ampak tudi s slikovno ponazoritvijo priseljencev. Fotografija jih prikazuje pri opravljanju najtežjih fizičnih del.

V učbeniku Geografija Evrope in Azije (Senegačnik, 2013a) se migracije med vsemi učbeniki za 7. razred omenjajo največkrat, vendar praviloma bolj na kratko, čeprav se 
njihova obravnava največkrat ne omejuje le na en stavek. Pri sklopu o Južni Evropi se omenjajo izseljenci v Ameriko ter priseljevanje v velika mesta. Pri sklopu o Zahodni Evropi se omenjajo selitve s podeželja v mesto v začetku industrializacije. Precej več pozornosti (dva odstavka) je namenjeno izseljevanju z Irske v Ameriko in v novejšem času tudi nazaj. Pri obravnavi Severne Evrope je omenjeno, da je ta del celine odprl vrata beguncem z vsega sveta, v rubriki Kdo želi vedeti več pa so na kratko opisane selitve Samijev s čredami severnih jelenov. V poglavju o Vzhodni Aziji je z več stavki razložen pojav nomadizma, kar je podkrepljeno tudi s fotografijo. V poglavju o Jugozahodni Aziji pojem 'migracije' neposredno ni omenjen, je pa govora o tujih delavcih v naftnih državah, kar je podkrepljeno tudi s fotografijo.

Pouk geografije v osmem razredu je namenjen obravnavi Afrike, Avstralije, Amerike in polarnih območij. Glavnina obravnave migracij je razumljivo namenjena priseljevanju v Novi svet, to je v obe Ameriki in Avstralijo z Oceanijo. Učbenik Geografija 8 (Resnik Planinc, Bahar, Račič, 2012) omenja migracije na več mestih, vendar se ne spušča v obširnejšo obravnavo. Pri obravnavi prebivalstva Afrike je omenjeno priseljevanje na dve znani rudarski območji, pri obravnavi Južne Afrike pa so omenjeni delavci iz sosednjih držav. Nekoliko obširneje je prikazano priseljevanje v Avstralijo v različnih obdobjih, omenjene so tudi selitve novozelandskih Maorijev ter drugih prebivalcev Oceanije v mesta. Pri obravnavi Amerike so omenjeni prisilni 'umik' Indijancev z njihovih ozemelj v bolj sušna območja, naseljevanje goratega zahoda in Kanade ter nasilno dovažanje afriških sužnjev v Srednjo Ameriko. Medtem ko so vse te omembe migracij omejene na stavek ali kvečjemu dva, je v obravnavo prebivalstva ZDA vključen tudi nekoliko obširnejši opis priseljevanja $\mathrm{v}$ ZDA.

$\mathrm{Na}$ še več mestih omenja migracije učbenik Geografija za 8. razred (Novak, Otič, Korže Vovk, 2004). V poglavju o Afriki so omenjene pri razlagi selilnega poljedelstva v Vzhodni Afriki, pri nasilnem odvažanju sužnjev iz Zahodne Afrike v Ameriko in pri naseljevanju Evropejcev v Južno Afriko. Še več prostora je priseljevanju namenjeno pri obravnavi Amerike. Na več mestih je nekoliko obširneje predstavljeno priseljevanje Evropejcev in afriških sužnjev tako v Angloameriko kot Latinsko Ameriko, njihovo mešanje s staroselci in nastanek etničnega mozaika, kar je prikazano tudi s posebno karto in fotografijo. Na kratko je predstavljeno tudi nasilno preseljevanje Indijancev, naseljevanje ameriškega Divjega zahoda, zbiranje znanstvenikov v Silicijevi dolini in izseljevanje Mehičanov v ZDA.

V podobnem obsegu predstavlja migracije tudi učbenik Raziskujem Novi svet 8 (Verdev, 2010b). Na kratko (v stavku ali dveh) so omenjene v poglavju o Afriki (preseljevanje v Sahelu zaradi suše, priseljevanje v Afriko v kolonialnem obdobju in v novejšem času, novodobne selitve v mesta). Precej bolj podroben prikaz migracij je v poglavjih o Severni in Južni Ameriki. Severna Amerika je že v uvodu navedena kot celina priseljencev. Priseljevanje v ZDA z različnih koncev sveta, stapljanje narodov in izrivanje staroselcev so prikazani v dveh podpoglavjih v različnih delih učbenika. Na podoben način je v posebnem podpoglavju prikazano tudi priseljevanje v Kanado. Pri ZDA so omenjene tudi selitve s podeželja $v$ mesta. V nadaljevanju učbenika je na kratko omenjeno priseljevanje v Srednjo Ameriko. V zaključnem pregledu Amerike so v posebni rubriki izpostavljene 
sodobne socialno in etnično pogojene migracije znotraj mest. S kratkim komentarjem in fotografijo je avtorica opozorila tudi na nezakonito priseljevanje iz Mehike v ZDA. V samostojnih podpoglavjih je avtorica predstavila tudi priseljevanje v Avstralijo in na

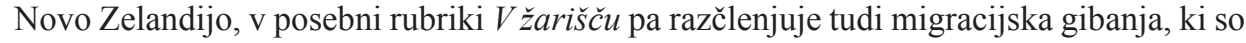
sledila osvajanju drugih dežel po obdobju velikih geografskih odkritij.

Najizčrpneje so migracije prikazane v učbeniku Geografija Afrike in Novega sveta (Kolnik in sod., 2010). Pri Afriki se v glavnem le omenjajo v stavku ali dveh (naseljevanje Afričanov zaradi razvoja pomorstva, trgovine in naftnega gospodarstva ob gvinejski obali, selitve v Sahelu kot beg pred sušo, priseljevanje v Južno Afriko), izčrpneje pa so prikazane pri vsebinskem sklopu o Avstraliji in Oceaniji. Migracije so omenjene že pri etnogenezi Aboriginov, predvsem pa na več mestih in v več odstavkih pri prikazu priseljevanja Evropejcev in v novejšem času tudi drugih priseljencev v Avstralijo in Novo Zelandijo. Priseljevanje in njegove posledice v obliki etničnih trenj je omenjeno tudi pri obravnavanju Oceanije.

Še obširnejši prikaz priseljevanj in spajanja različnih kultur v večkulturno družbo je v obliki dveh posebnih podpoglavij pri vsebinskem sklopu o Angloameriki, kjer je besedilo podkrepljeno tudi s posebno karto priseljevanja in fotografijo večkulturne družbe. Posebno podpoglavje je namenjeno sodobnim selitvam znotraj ZDA, kjer je poudarjeno, da se nikjer drugje na svetu ljudje ne selijo toliko kot v ZDA. To besedilo je ponazorjeno tudi s fotografijo posebnih premičnih hiš. Pri Angloameriki so migracije omenjene še na več mestih in v različnem kontekstu (razlaga pojmov 'Anglomerika' in 'Latinska Amerika', razlike med 'starim' priseljevanjem iz Evrope in 'novim' priseljevanjem iz Latinske Amerike in Azije, prisilno preseljevanje Indijancev, prihod Inuitov iz Azije), vendar praviloma le v stavku ali dveh. Nekoliko bolj na kratko so migracije predstavljene pri vsebinskem sklopu o Latinski Ameriki. Povečini so krajše omembe v stavku ali dveh (priseljevanje Špancev in Portugalcev po Kolumbovem prihodu, selitve s podeželja v mesta, prihod afriških sužnjev, selitve iz Mehike v ZDA, novodobno izseljevanje s karibskih otokov, sedanje priseljevanje kolonistov v Amazonijo). Sodobno priseljevanje je omenjeno tudi pri vsebinskem sklopu o polarnih območjih.

Za zaključek osnovnošolskega izobraževanja sledi v 9. razredu še geografija domače države Slovenije. V učbenikih je obravnava praviloma ločena na občegeografski prikaz Slovenije na eni in regionalnogeografski prikaz slovenskih makroregij na drugi strani. Migracije se največ obravnavajo v občegeografskem prikazu pri poglavju o prebivalstvu.

Učbenik Geografija Slovenije za 9. (8.) razred (Novak, 2003) ima v prvem delu pregled makroregij. V večjem delu učbenika so migracije omenjene le v stavku ali dveh (omemba izseljencev pri položaju Slovenije v Evropi, nemško priseljevanje v Slovenijo v preteklosti, dnevne migracije v Ljubljano, novodobno odseljevanje z dinarskih planot in iz panonskih pokrajin, priseljevanje s podeželja in drugih delov Jugoslavije v Maribor, versko pogojene selitve v preteklosti v Prekmurju, priseljevanje v Slovenijo iz drugih republik v času povojne industrializacije). Obširneje so migracije predstavljene v poglavju o prebivalstvu na koncu učbenika, kjer je selitvam (odseljevanju in priseljevanju) posvečen poseben odstavek, posebno podpoglavje pa je namenjeno še izseljenstvu in zdomstvu. Izseljenstvo je razčlenjeno glede na vzroke in smeri izseljevanja. 
Učbenik Geografija 9 (Račič, Večerič, 2009) začenja obravnavo Slovenije z občegeografskim pregledom naše države. V poglavju o prebivalstvu je obširen odstavek o različnih oblikah migracij (izseljenstvo, zdomstvo, priseljevanje v Slovenijo iz drugih jugoslovanskih republik). Priseljevanje iz drugih republik je vključeno tudi v razlago narodne sestave. V nadaljevanju učbenika so migracije pri obravnavi slovenskih makroregij omenjene le v stavku ali dveh (odseljevanje iz višjih leg pri alpskih pokrajinah, izseljevanje v Ameriko, zapuščanje vasi in preselitev Kočevarjev pri dinarskokraških pokrajinah, izseljevanje iz Brkinov pri primorskih pokrajinah).

Tudi v učbeniku Raziskujem Slovenijo 9 (Verdev, 2011) so migracije dokaj podrobno predstavljene le v občegeografskem delu v poglavju o prebivalstvu, kjer so razčlenjene glede na oblike, vzroke, čas in smer, ter v rubriki $V \check{z}$ arišču, kjer je govora o Slovencih po svetu. Zdomcem in izseljencem sta namenjena posebna odstavka $\mathrm{z}$ dvema fotografijama. Omenjeni so tudi v drugih delih učbenika, in sicer pri zgodovini državnih tvorb na slovenskem ozemlju, narodni sestavi prebivalstva ter pri obravnavi predalpskih pokrajin (izseljevanje iz predalpskih hribovij), panonskih pokrajin (beg z dežele), dinarskokraških pokrajin (odseljevanje $\mathrm{z}$ dinarskih planot) in primorskih pokrajin (priseljevanje v Koper in Novo Gorico, povojno odseljevanje Italijanov z obalnih območij in priseljevanje iz drugih republik).

Najobširneje so migracije predstavljene v učbeniku Geografija Slovenije (Senegačnik, 2012b). Tudi ta ima v prvem delu občegeografski pregled, v drugem pa sledi obravnava makroregij. V poglavju o prebivalstvu sta v podpoglavju o gostoti prebivalstva omenjena tudi 'beg z dežele' in 'beg z gora', nato pa sledi posebno podpoglavje z naslovom Preobrazba iz dežele odseljevanja $v$ deželo priseljevanja. Selitve iz Slovenije in v Slovenijo so razčlenjene glede na obliko, vzroke, čas in smeri, kar je podkrepljeno še s karto, grafikonom in dvema fotografijama. V posebni rubriki Ali veš je še kratek sestavek o naravnem in selitvenem prirastu drugod po Evropi, ki je ponazorjen z grafikonom. Posebno podpoglavje je namenjeno tudi izseljencem po svetu. Krajšemu besedilu je dodana karta držav, kjer živijo Slovenci. V ostalih delih učbenika so migracije samo omenjene v poglavjih o naseljih (novodobne selitve v predmestja) in prometu (dnevne migracije), pri obravnavi predalpskih pokrajin (dnevne migracije v Ljubljanski kotlini), dinarskih pokrajin (krošnjarjenje Ribničanov), obsredozemskih pokrajin (odseljevanje iz odročnih predelov) in obpanonskih pokrajin (odseljevanje iz te makroregije).

Pregled osnovnošolskih učbenikov lahko zaključimo z ugotovitvijo, da pogostnost in zahtevnost obravnave migracij v precejšnji meri naraščata s starostno stopnjo, zaradi katere se povečuje zmožnost učencev za dojemanje zahtevnejših pojmov, kar se posledično kaže tudi v zahtevnosti učbenikov. V 6. razredu se migracij še ne obravnava, v 7. razredu so bolj ali manj le omenjene, obširnejšo obravnavo pa imajo v 8. razredu (predvsem pri priseljevanju v Novi svet) in v 9. razredu pri geografiji Slovenije (predvsem v poglavju o prebivalstvu).

\section{MIGRACIJEV UČBENIKIH ZA GIMNAZIJSKI PROGRAM}

V gimnazijskem programu je v prvem letniku obča geografija, v višjih letnikih pa sledijo regionalna geografija sveta, Evrope in Slovenije. Dijaki se v prvem letniku seznanijo s temelji geografije, nato pa preidejo na bolj problemsko zasnovano regionalno geografijo in nekatere 
druge učne vsebine, ki jih postavijo na že usvojene temelje iz obče geografije. Velik problem pri takšni razporeditvi se kaže v tem, da je obča geografija najzahtevnejši del gimnazijske geografije, hkrati pa je na vrsti takoj na začetku gimnazijskega programa. Obravnava migracij je tako v učnem načrtu kot $v$ učbenikih predvidena šele $v$ drugi polovici šolskega leta, v prvem družbenogeografskem vsebinskem sklopu o prebivalstvu. Dijaki se tukaj seznanijo z različnimi oblikami migracij, ki jih v višjih letnikih gimnazije spoznavajo na konkretnih primerih.

Učbenik Obča geografija za 1. letnik gimnazijskega in srednjega tehniškega oz. strokovnega izobraževanja (Cunder in sod., 2006) obravnava migracije izključno v poglavju o prebivalstvu. Selitvam je posvečeno posebno podpoglavje, ki obsega cele tri strani z dvema kartama, dvema grafikonoma in devetimi fotografijami. Migracije so opredeljene glede na vrsto kriterijev (čas, smer, vrsta, prostovoljnost in drugo), pojasnjen je tudi pojem 'migracijska politika'. Podpoglavju o selitvah sledi obravnava demografskih območjih, ki jih ni moč razložiti brez selitev. Tudi pri teh učnih vsebinah so dodane tri fotografije - v nobenem drugem gimnazijskem učbeniku ni pri obravnavi migracij toliko in tako nazornih ilustracij.

Tudi v učbeniku Geografija 1 (Popit, 2011) so migracije obravnavane v poglavju o prebivalstvu, in sicer v posebnem podpoglavju z naslovom Selitve. Razčlenjene so glede na kraj oziroma smer, motive, razloge in druge kriterije. $Z$ dvema shemama so prikazani dejavniki priseljevanja in odseljevanja, v dveh rubrikah Pogled v svet sta obširneje razložena primera ekonomskih migracij med Turčijo in Nemčijo in političnih migracij v Darfurju. Na koncu poglavja o prebivalstvu je še posebno podpoglavje z naslovom Regionalni pregled - ključni demografski procesi in različnosti. V njem je na kratko omenjeno priseljevanje v Ameriko in Avstralijo, dodane so štiri nazorne karte.

Učbenik Obča geografija za 1. letnik gimnazij (Senegačnik, Drobnjak, 2013) se loteva migracij samo v vsebinskem sklopu o prebivalstvu, kjer jim je namenjeno posebno, a kratko poglavje z naslovom Selitve. Razdeljeno je na tri podpoglavja: prvo obravnava vzroke za selitve, v njem so razloženi tudi osnovni pojmi v zvezi z migracijami. Besedilo je ponazorjeno s fotografijo in grafikonom, v rubriki Primer pa so predstavljene selitve po razpadu nekdanje Jugoslavije. Drugo podpoglavje je namenjeno oblikam selitev glede na prostor, čas in druga merila. Tudi to besedilo je ponazorjeno $\mathrm{z}$ grafikonom in fotografijo, $\mathrm{v}$ rubriki Za kanček več pa je prikazana problematika beguncev v svetu in pri nas. V tej rubriki je tudi karta razporeditve beguncev po svetu. Tretje podpoglavje obravnava posledice selitev in tipe demografskih območij; besedilo ponazarjata dve fotografiji.

V drugem letniku gimnazije so učni cilji namenjeni regionalni geografiji sveta brez Evrope, ki se jo obravnava kasneje. Učbenik Svet (Senegačnik, 2012c) se migracij loteva na številnih mestih, vendar v veliki meri le z enim ali dvema stavkoma. V vsebinskem sklopu o Aziji sta pri poglavju o kmetijstvu pojasnjena pojma 'selilno poljedelstvo' in 'nomadizem', v poglavju o prebivalstvu pa načrtno razseljevanje prebivalstva v Indoneziji. Pri vsebinskem sklopu o Afriki sta pri prebivalstvu omenjena nasilno odvažanje afriških sužnjev ter novodobni problem beguncev, pri poglavju o kmetijstvu pa sta opisana selilno poljedelstvo in nomadizem.

Precej pogosteje so migracije omenjene pri Latinski Ameriki, a povečini le v enem ali dveh stavkih (prebivalstvene spremembe po prihodu Evropejcev v Novi svet, priseljevanje 
Evropejcev in Afričanov in njihovo stapljanje v pisan mozaik prebivalstva). Nekoliko obširneje so migracije obdelane v podpoglavju z naslovom Zapuščanje podeželja in problemi velikih mest, nekaj je o njih povedano tudi pri širjenju in problemih mehiške prestolnice. Priseljevanje se omenja tudi pri obravnavi posameznih geografskih enot Južne Amerike: posebej je izpostavljeno v nižinskem delu Peruja, na jugu Južne Amerike, na jugovzhodu Brazilije ter v Amazoniji. V rubriki Primer je razloženo tudi priseljevanje Slovencev v Argentino.

Precej podrobneje so migracije predstavljene pri vsebinskem sklopu o Severni Ameriki. Namenjeno jim je posebno podpoglavje z naslovom Naselitev je potekala $v$ več valovih, na koncu katerega je rubrika Primer v celoti posvečena novodobnemu ilegalnemu priseljevanju Mehičanov v ZDA. V podpoglavju sta tudi dve karti. Posledice priseljevanja in mešanja prebivalstva so obširno predstavljene v podpoglavju z naslovom $O d$ 'talilnega lonca' do 'mozaične kulture' oziroma 'kulturnega mozaika'. To podpoglavje, ki vsebuje tudi štiri grafikone, tri karte in fotografijo, predstavlja najobširnejši in najbolj celovit prikaz posledic migracij v vseh naših gimnazijskih učbenikih. Nekaj besed je migracijam namenjenih tudi v naslednjih dveh podpoglavjih o ameriškem mestu in poselitvenih razmerah. Obe sta opremljeni z več fotografijami in kartami, ki pa se le delno nanašajo na migracije. Izpostaviti je treba še rubriko Za kanček več na koncu drugega od teh podpoglavij, ki je namenjena ameriškemu načinu življenja in mobilnosti prebivalstva. Opremljena je tudi s posebno fotografijo. Migracije so na kratko omenjene še pri selitvah ameriške industrije in nastanku Silicijeve doline v Kaliforniji.

V poglavju o prebivalstvu Avstralije ima prvo podpoglavje naslov Celina priseljen$c e v$. V njem so dokaj podrobno opisani pretekli in sodobni razvoj priseljevanja v Avstralijo po opustitvi politike 'bele Avstralije' ter novejša politika multikulturnega razvoja; ob besedilu sta tudi dva grafikona in tri fotografije. Priseljevanje je na kratko omenjeno tudi pri Novi Zelandiji ter pri izkoriščanju naravnih bogastev v Arktiki.

Tudi učbenik Geografske značilnosti sveta za 2. letnik gimnazijskega in srednjega tehniškega oz. strokovnega izobraževanja (Kürbus in sod., 2004) velikokrat omenja migracije, obširneje pa jih razčlenjuje le na nekaterih mestih, in sicer pri poglavjih o prebivalstvu priseljeniških celin Amerike in Avstralije. Pri vsebinskem sklopu o Aziji so v poglavju o prebivalstvu zgolj omenjene, pri vsebinskem sklopu o Afriki pa jih učbenik omenja kot posledico genocida v Ruandi, v zvezi z vojno v Somaliji, pri opredeljevanju selilnega poljedelstva in nomadizma, pri vzrokih za lakoto in pri posledicah suše v Sahelu. Ravno tako so migracije bolj ali manj le omenjene pri vsebinskem sklopu o Latinski Ameriki v zvezi s priseljevanjem Evropejcev, pri razvojnih problemih Mehike in tamkajšnjih vzrokih za 'beg z dežele' ter pri novem naseljevanju Amazonskega nižavja.

Povsem drugačna je obravnava migracij pri vsebinskem sklopu o Severni Ameriki. Tam je posebno, osem strani dolgo poglavje z naslovom Kolonizacija, poselitev, selitve in urbanizacija ZDA. Migracije so razčlenjene tako v osnovnem besedilu kot pri dodatnih vsebinah, poglavje je tudi bogato opremljeno s fotografijami, kartami in drugimi dodatki. Migracije so na kratko omenjene tudi pri obravnavanju položaja staroselcev in priseljevanja v Kanado. Tudi pri vsebinskem sklopu o Avstraliji je priseljevanje opisano dokaj podrobno in ponazorjeno s posebno karto. Zgodovinsko priseljevanje staroselcev je omenjeno tudi pri Novi Zelandiji. 
Za pouk geografije Evrope sta v gimnazijskem programu v uporabi dva učbenika. Učbenik Geografske značilnosti Evrope za 2. in 3. letnik gimnazij (Bola Zupančič in sod., 2002) je zasnovan tematsko. Migracije se omenjajo na več mestih v osnovnem besedilu in pri študijah primerov, ki jih je v tem učbeniku veliko in se ponekod po pomenu sploh ne razlikujejo od osnovnega besedila. $Z$ enim ali dvema stavkoma so omenjene v uvodnem poglavju Lega in meje Evrope, pogosteje in obširneje so omenjene ter pojasnjene v poglavju o prebivalstvu, in sicer pri študijah primerov o Utrechtu in Trakiji ter v podpoglavjih o razvoju prebivalstva in narodnih manjšinah. V poglavju o prebivalstvu je manjšinam posvečeno tudi štiri strani dolgo podpoglavje z naslovom Selitve, selitve, selitve, v katerem so migracije razčlenjene glede na dejavnike priseljevanja, omenjeni so pojmi omejevalne politike, azilantov in ilegalnih priseljencev. Podrobno so analizirani vzroki za predvideno povečevanje priseljevanja v Evropo, mnenje (dela) javnosti o priseljevanju, problem beguncev in posledice schengenskega sporazuma. V podpoglavju najdemo kar štiri karte, dva grafikona in štiri fotografije, ki se navezujejo neposredno na migracije. Slednje so na kratko omenjene tudi v drugih študijah primerov, ki jih najdemo v nadaljevanju učbenika (o Ukrajini, industrijskem razvoju Velike Britanije, Porurju in Švedski) ter v zadnjem poglavju o delitvi Evrope.

Učbenik Evropa, Geografija za 2. in 3. letnik gimnazij (Senegačnik, Lipovšek, Pak, 2009) ima kombiniran pristop, kar pomeni, da občegeografskemu uvodnemu delu sledi obravnava posameznih geografskih enot. V uvodnem delu je v poglavju o družbenih procesih v rubriki Za kanček več omenjeno priseljevanje muslimanskega prebivalstva, sicer pa je migracijam namenjeno celo podpoglavje z naslovom Selitve prebivalstva so močno spremenile podobo Evrope na skoraj štirih straneh. Migracije so razčlenjene glede na vzroke, analizirane so tudi smeri migracijskih tokov ter današnji položaj priseljencev in njihovih potomcev. Znotraj podpoglavja sta v rubriki Primer predstavljeni dve kratki študiji primera. Prva govori o tem, zakaj je Južna Evropa 'magnet' za priseljence, druga pa o nemirih v priseljenskih četrtih v Franciji leta 2005. Podpoglavje o migracijah je opremljeno s sedmimi kartami, dvema grafikonoma in štirimi fotografijami. V prvem, občegeografskem delu učbenika so migracije na kratko omenjene tudi pri razporeditvi prebivalstva in učinkih skupne kmetijske politike EU.

Drugi, obsežnejši del učbenika je namenjen obravnavi evropskih geografskih enot in osrednjih geografskih problemov tamkajšnjih držav, pri čemer so migracije skoraj povsod omenjene le v stavku ali dveh. Pri vsebinskem sklopu o Vzhodni Evropi se omenjajo v rubriki Primer pri obravnavi nafte in plina v zahodni Sibiriji ter v podpoglavju o posebnostih razvoja prebivalstva v Rusiji. Pri vsebinskem sklopu o Srednji Evropi se omenjajo v podpoglavju o Nemčiji z naslovom Ena država - dva svetova, nanje opozarja tudi karta gibanja števila prebivalcev v zahodnem in vzhodnem delu države. Migracije so omenjene tudi pri prestrukturiranju nemškega Porurja in poljskega Gornješlezijskega industrijskega bazena. Pri Severni Evropi se omenjajo pri spremembi gospodarske strukture na Norveškem, smeri migracij s severa na jug države so prikazane z nazorno karto. Na kratko so omenjene še pri razvoju rudarskega mesta Kiruna na Švedskem in pri spreminjanju narodnostne sestave pribaltskih držav.

Nekaj več pozornosti je selitvam namenjeno v vsebinskem sklopu o Zahodni Evropi. Omenjene so pri členitvi Velike Britanije in njenih regionalnih razlikah, še več prostora 
jim je namenjeno v podpoglavjih o urbanizaciji te države in nekdanjem množičnem izseljevanju z Irske. Pri vsebinskem sklopu o Južni Evropi se migracije omenjajo že v uvodnem napovedniku, nato v podpoglavjih o kmetijstvu Južne Evrope, spremenjeni demografski podobi Iberskega polotoka in italijanskem Mezzogiornu. Enako so omenjene že v napovedniku za Jugovzhodno Evropo, potem pa nekoliko podrobneje razčlenjene v podpoglavjih o posledicah etničnega čiščenja v Bosni in Hercegovini ter o etničnih trenjih na Kosovu in v Makedoniji. Smeri begunskih tokov na območju nekdanje Jugoslavije so prikazane tudi na karti. V zaključnem delu učbenika je v posebnem podpoglavju razčlenjen in na karti prikazan eksodus prebivalstva iz Albanije po odpravi socializma.

$\mathrm{Na}$ koncu gimnazijskega programa pride na vrsto geografija Slovenije, za katero so založbe pripravile po dva učbenika. Prvi, občegeografski del geografije Slovenije je uradno v programu v 3. letniku, drugi, regionalni del pa je v programu za 4. letnik. Učbenik Geografske značilnosti Slovenije za 3. letnik gimnazijskega in srednjega tehniškega oz. strokovnega izobraževanja (Likar, Popit, Šturm, 2006) se migracij loteva predvsem v poglavju o prebivalstvu. Najprej so na kratko omenjene v podpoglavju o naravnem prirastku, v podpoglavju z naslovom Selitve pa jim je namenjena več kot eno stran. Tu je kronološko obdelano izseljevanje iz Slovenije, nato sledi opis priseljevanja, ponazorjen z grafikonom; vključeni sta tudi dve fotografiji. V nadaljevanju učbenika so migracije omenjene le še s stavkom ali dvema, in sicer pri obravnavi mest, sprememb na podeželju, kmetijstva in industrije.

Na zelo podoben način se migracij loteva tudi učbenik Geografija Slovenije 1, Učbenik za 3. letnik gimnazij (Klemenčič, Lipovšek, 2002). Najprej so le na kratko omenjene pri obravnavi vloge Slovenije v Evropi in svetu, razvoja poselitve, gostote prebivalstva, Slovencev v zamejstvu in svetu. Precej podrobneje so predstavljene v poglavju z naslovom Preštejmo se, kjer je najprej predstavljeno obdobje izseljevanja do 2 . svetovne vojne in nato še obdobje povojnega priseljevanja. Prikaz je ponazorjen tudi z grafikonom. V nadaljevanju učbenika so migracije omenjene le še v stavku ali dveh pri suburbanizaciji in spreminjanju podeželja.

Skoraj enak pristop uporablja tudi učbenik Slovenija 1, Geografija za 3. letnik gimnazij (Senegačnik, 2013c). Migracije v naši državi zelo podrobno obravnava v poglavju o prebivalstvu, v katerem so štiri podpoglavja: Odseljevanje, priseljevanje in razvoj skupnega števila prebivalcev, Notranje selitve in dnevna migracija, Število zdomcev se je zmanjšalo ter Slovenija je bila dolgo dežela izseljencev. Besedilo je ponazorjeno s štirimi grafikoni, štirimi kartami in dvema fotografijama. V nadaljevanju učbenika so migracije le še omenjene pri obravnavi Slovencev v Avstriji in na Madžarskem, razvoju slovenskih mest, suburbanizaciji in zmanjševanju pomena kmetijstva.

Za pripravo na maturo so v uporabi trije učbeniki, ki dokaj sistematično obravnavajo slovenske makroregije. Učbenik Geografske značilnosti Slovenije (Petek, Popit, Arnuš, 2007) omenja migracije na več mestih, a le v stavku ali dveh pri nekaterih makroregijah: pri Predalpskih pokrajinah, v študiji primera o Ljubljani, pri Vzhodnem Predalpskem hribovju in Velenjski kotlini, pri Submediteranskih pokrajinah, pri študiji primera o spreminjanju obale, pri Dinarskokraških pokrajinah, pri Kočevarjih in Beli krajini, Dolenjskem podolju, Kozjanskem, Halozah in Slovencih na Madžarskem. 
Na več mestih, vendar brez podrobnosti, so omenjene migracije tudi v učbeniku Geografija Slovenije 2, Priprava na maturo (Klemenčič, Lipovšek, 2003), in sicer pri obravnavi Dravske doline in Pohorja, Ljubljanske kotline in mesta Ljubljane, flišnih pokrajin na Goriškem, Kopra, visokih dinarskih planot in robnih delov Subpanonske Slovenije. Skoraj povsem enako ugotovitev lahko damo tudi za učbenik Slovenija 2, Geografija za 4. letnik gimnazij (Senegačnik, 2011). V njem so migracije omenjene pri opisih in razlagah alpske poselitve, planinskega pašništva, Zgornjesavske doline z Jesenicami, Idrije, Škofje Loke, Črnega revirja, Velenja, Pohorskega Podravja, Ljubljanske kotline in Ljubljane, posledic spreminjanja državnih meja na Primorskem, Nove Gorice, Brkinov, Koprskega gričevja, Kočevarjev in Kočevskega, zdomstva v Obpanonskih pokrajinah, Rezije in Slovenskega Porabja.

\section{MIGRACIJEV UČBENIKIH ZA NEGIMNAZIJSKE PROGRAME}

Negimnazijskih programov je več in imajo različno število ur geografije. Na splošno je obseg geografije $\mathrm{v}$ teh programih neprimerno bolj okrnjen kot v gimnazijskem programu, temu pa sledijo tudi učbeniki. Ker so se založbe zaradi večjega povpraševanje bolj osredotočile na osnovno šolo in gimnazijski program, imamo tu na voljo manjše število učbenikov.

Daleč najobsežnejši je učbenik Geografija za srednje šole (Kunaver in sod., 2004). Pri tem delu gre za razširjeno verzijo obče geografije za gimnazijski program, zato so v njem podrobnosti, ki jih v drugih učbenikih ne najdemo. Migracijam je namenjeno posebno podpoglavje v okviru poglavja Gibanje števila prebivalcev. Podpoglavje je razdeljeno na tri vsebinske sklope: Pojem selitev ali migracij, Vzroki in motivi selitev ter Oblike selitev. Precej podrobno besedilo dopolnjujeta dva grafikona, karta in fotografija. Nekaj malega se o migracijah govori tudi v podpoglavjih o skupnem gibanju števila prebivalcev, razvoju in urbanizaciji vaških naselij ter podobi in zgradbi mest. V okviru obravnave mestnega prebivalstva je migracijam namenjen poseben vsebinski sklop z naslovom Mesto je prostor živahnih selitev prebivalstva.

Učbenik Družboslovje. Geografija (Cunder, 2006) je zasnovan podobno kot večina regionalnogeografskih učbenikov za gimnazije: najprej občegeografski pregled, nato regionalni del učbenika. Migracije se obravnavajo pri poglavju o prebivalstvu, kjer je posebno podpoglavje z naslovom Selitve prebivalstva. Avtorica najprej opredeli pojem migracij, potem pa jih razčlenjuje glede na vzroke in prostorski razpored, v nadaljevanju pa obravnava še problem beguncev in migracije v Sloveniji. Besedilo o beguncih dopolnjuje fotografija. Značilnost tega učbenika je rubrika Izpostavljena tema, v kateri so kot poseben primer $\mathrm{z}$ dovolj podrobnim besedilom in dvema kartama predstavljene migracije Judov v Izrael. V nadaljevanju so selitve omenjene le še pri obravnavi mestnih naselij in problemov velikih mest.

Kljub enakemu naslovu ima nekoliko drugačen koncept učbenik Družboslovje. Geografija (Kunaver in sod., 2011). Migracije se omenjajo le v stavku ali dveh v drugem vsebinskem sklopu Slovenija, in sicer v kratkih poglavjih o Alpskem svetu, Subpanonski 
Sloveniji, Primorskem svetu, slovenski industriji, poselitvi Slovenije in skladnejšem regionalnem razvoju. Nekoliko obširneje se omenjajo v tretjem vsebinskem sklopu z naslovom Slovenija v Evropi in svetu, kjer je kratko podpoglavje z naslovom Najrazvitejše evropske države so privlačne za priseljevanje, temu pa je priložena tudi karta migracij v Evropi. Posebna pozornost je migracijam namenjena tudi v četrtem vsebinskem sklopu učbenika z naslovom Sodobni svet, kjer je poglavje Širni svet vabi. Tu so na kratko razložene vrste selitev, nato je v nekaj odstavkih obravnavano priseljevanje v ZDA, v zahodni del Evrope in Rusijo po razpadu Sovjetske zveze. Besedilo je dopolnjeno z nazornim grafikonom in tremi fotografijami. Na koncu poglavja so pojasnjeni še pojav begunstva $\mathrm{V}$ Afriki in Vietnamu ter priseljevanje v Slovenijo. V posebnem poglavju Krizna žarišča po svetu je podrobno prikazano priseljevanje v Izrael z vsemi posledicami, ki jih je to imelo za palestinsko prebivalstvo.

Spet drugačen pristop uporabljata učbenika Svet okoli nas 1 (Likar, 2006a) in Svet okoli nas 2 (Likar (2006b). Napisana sta dokaj 'klasično' po poglavjih obče geografije, z nekaterimi vsebinskimi dodatki; prvi učbenik obravnava le fizično, drugi le družbeno geografijo. V prvem učbeniku migracije niso omenjene, z izjemo predstavitve življenja na obalah, več o njih je v drugem učbeniku. Podobno kot v učbenikih obče geografije so migracije tudi tu prikazane dokaj podrobno v okviru poglavja o prebivalstvu v posebnem podpoglavju z naslovom Selitve. Najprej je razložen pojem migracij, sledijo obravnave njihove delitve na dve osnovni skupini, vzrokov za selitve, posledic selitev v državah odseljevanja in priseljevanja, asimilacije ter tipov demografskih območij. Ob tem besedilu je kar 11 fotografij in ena karta. Učbenik ima tudi posebno rubriko Izpostavljena tema, v kateri je na celi strani predstavljena problematika beguncev in ilegalnih priseljencev ter dodane tri fotografije. V nadaljevanju učbenika so migracije omenjene le s stavkom ali dvema pri verski sestavi prebivalstva, pri urbaniziranih podeželskih naseljih, pri kmetijstvu v Sloveniji ter pri posledicah vstopa Slovenije v Evropsko unijo.

\section{SKLEP}

Migracije so družbeni pojav, ki je pogosto predmet geografskega raziskovanja, zato ne preseneča, da jih obravnavajo tako rekoč vsi geografski učbeniki za različne starostne stopnje in vrste izobraževanja. Edina izjema so le učbeniki za 6. razred osnovne šole. Raziskava je zajela geografske učbenike, ki so se na slovenskih šolah uporabljali v šolskem letu 2012-2013, in smo jih razdelili v tri skupine.

Prvo skupino predstavljajo učbeniki za osnovno šolo. Ker se 'mala obča geografija' v šestem razredu (kot neke vrste izjema) z migracijami še ne ukvarja, si učenci znanje o njih v osnovni šoli pridobivajo po induktivni poti. To pomeni, da pri regionalni geografiji Evrope, neevropskih celin in Slovenije spoznavajo posamezna dejstva o migracijah (povečini na konkretnih primerih) in iz njih izvajajo obča in abstraktna spoznanja. Osnovnošolska geografija praviloma podaja osnovne informacije o pojmih, ki se jih ponovno obravnava tudi na srednješolskem nivoju, vendar tam dijaki dobijo o njih bolj problemsko orientirane informacije. Zahtevnost obravnave migracij se v osnovnošolskih učbenikih postopoma stopnjuje, podobno velja tudi za pogostnost njihove obravnave. Migracije se 
v osnovnošolskih učbenikih največkrat obravnavajo pri vsaki celini posebej v poglavjih o prebivalstvu, pri čemer je pozornost največkrat usmerjena k preteklim (zgodovinskim) migracijam in ne k sedanjim. Priseljevanje se obravnava večkrat kot odseljevanje, kar kaže, da gre pri osnovnošolski geografiji bolj za osnovne kot za problemske informacije o določenih tematikah.

Gimnazijski program se začenja z učbenikom obče geografije, zato dijaki znanje o migracijah pridobivajo in širijo po deduktivni poti. Najprej usvojijo obča spoznanja o migracijah, potem pa v višjih letnikih gimnazije bolj poglobljeno in bolj problemsko orientirano spoznavajo konkretne primere na neevropskih celinah, v Evropi in na koncu še v Sloveniji. V učbenikih obče geografije za prvi letnik je velika večina vseh vsebin o migracijah zgoščena v vsebinskem sklopu o prebivalstvu, v katerem se dijaki temeljito spoznajo z vsemi vrstami in oblikami migracij. V višjih letnikih spoznavajo migracije na konkretnih primerih, najbolj poglobljeno ravno pri regionalni geografiji Novega sveta, kjer so pretekla priseljevanja najbolj zaznamovala današnjo podobo teh celin.

$\mathrm{V}$ učbenikih za negimnazijske programe ni moč zaslediti enotnega pristopa pri obravnavi migracij. V nekaterih se uporablja deduktivni pristop, ki močno spominja na tistega $\mathrm{v}$ gimnazijskem programu, pri drugih pa gre za induktivni pristop oziroma kombinacijo obeh.

\section{Viri in literatura}

Besednjak, M., Dimnik, Z., Likar, M., Pušnik Bruderman, M., Klemen, J., Lipovšek, I., 2007. Učni načrt (predlog). Srednje strokovno in srednje poklicno-tehniško izobraževanje. Geografija. Ljubljana, Zavod RS za šolstvo, 16 str.

Bola Zupančič, K., Cunder, K., Popit, S., Gartner, M., Purger, S., 2002. Geografske značilnosti Evrope za 2. in 3. letnik gimnazij. 1. izd. Ljubljana, Mladinska knjiga, 88 str.

Cunder, K., 2006. Družboslovje. Geografija. Učbenik za nižje poklicno, srednje poklicno, poklicno-tehniško in srednje tehniško oz. strokovno izobraževanje. 1. izd. Ljubljana, Mladinska knjiga, 103 str.

Cunder, K., Hajdinjak, B., Kandrič, B., Kürbus, T., 2006. Obča geografija za 1. letnik gimnazijskega in srednjega tehniškega oz. strokovnega izobraževanja. 1. izd. Ljubljana, Mladinska knjiga, 152 str.

Good, C., Scates, D. E., 1967. Metode istraživanja u pedagogiji, psihologiji i sociologiji. Rijeka, Otokar Keršovani, 734 str.

Klemenčič, M. M., Lipovšek, I., 2002. Geografija Slovenije 1. Učbenik za 3. letnik gimnazij. 1. izd. Ljubljana, DZS, 107 str.

Klemenčič, M. M., Lipovšek, I., 2003. Geografija Slovenije 2. Priprava na maturo. Učbenik za 4. letnik gimnazij. 1. izd. Ljubljana, DZS, 75 str.

Kolnik, K., Korže Vovk, A., Otič, M., Senegačnik, J., 2010. Geografija Afrike in Novega sveta. Učbenik za 8. razred osnovne šole. 1. izd. Ljubljana, Modrijan, 115 str.

Kolnik, K., Otič, M., Cunder, K., Oršič, T., Lilek, D., 2011. Učni načrt. Program osnovna šola. Geografija. Ljubljana, Ministrstvo RS za šolstvo in šport, Zavod RS za šolstvo, 39 str. 
Kunaver, J., Lovrenčak, F., Senegačnik, J., Drobnjak, B., Pak, M., Luževič, M., Klemenčič, M. M., 2004. Geografija za srednje šole. Učbenik za pouk geografije v programih, ki imajo za predmet geografija namenjenih 140 ur. 1. izd. Ljubljana, DZS, 185 str.

Kunaver, J., Lipovšek, I., Pak, M., Luževič, M., Klemenčič, M. M., 2011. Družboslovje. Geografija. Učbenik za družboslovje v 1., 2. in 3. letniku srednjega strokovnega izobraževanja, srednjega poklicnega in nižjega poklicnega izobraževanja. 1. izd. Ljubljana, DZS, 131 str.

Kürbus, T., Hajdinjak, B., Kandrič, B., Šturm, S., 2004. Geografske značilnosti sveta za 2. letnik gimnazijskega in srednjega tehniškega oz. strokovnega izobraževanja. 1. izd. Ljubljana, Mladinska knjiga, 131 str.

Likar, M., 2006a. Svet okoli nas 1. Učbenik za geografijo v 1. letniku srednjega tehniškega oz. strokovnega in poklicno-tehniškega izobraževanja. 1. izd. Ljubljana, Mladinska knjiga, 99 str.

Likar, M., 2006b. Svet okoli nas 2. Učbenik za geografijo v 2. letniku srednjega tehniškega oz. strokovnega in poklicno-tehniškega izobraževanja. 1. izd. Ljubljana, Mladinska knjiga, 83 str.

Likar, M., Popit, S., Šturm, S., 2006. Geografske značilnosti Slovenije za 3. letnik gimnazijskega in srednjega tehniškega oz. strokovnega izobraževanja. 1. izd. Ljubljana, Mladinska knjiga, 99 str.

Lipovšek, I., Lilek, D, Polšak, A., Cunder, K., Resnik Planinc, T., Oršič, T., Dragoš, A., Kolenc Kolnik, K., Otič, M., Škof, U., Besednjak, M., Klemen, J., 2008. Učni načrt. Gimnazija. Geografija. Strokovna gimnazija. Ljubljana, Ministrstvo RS za šolstvo in šport, Zavod RS za šolstvo, 26 str.

Miklavc Pintarič, S., Popit, S., 2005. Geografija 7. Učbenik za pouk geografije v sedmem razredu devetletne osnovne šole. 1. izd. Ljubljana, DZS, 71 str.

Mužević, V., 1973. Metodologija pedagoškog istraživanja. Sarajevo, Zavod za izdavanje udžbenika, 664 str.

Novak, F., 2003. Geografija Slovenije za 9. (8.) razred. Učbenik za 9. razred devetletne in 8. razred osemletne osnovne šole. 1. izd. Ljubljana, DZS, 112 str.

Novak, F., Otič, M., Vovk Korže, A., 2004. Geografija za 8. razred. 1. izd. Ljubljana, DZS, 95 str.

Petek, M., Popit, S., Arnuš, M., 2007. Geografske značilnosti Slovenije. Priprava na maturo. Učbenik za 4. letnik gimnazijskega in srednjega tehniškega oz. strokovnega izobraževanja. 1. izd. Ljubljana, Mladinska knjiga, 79 str.

Polšak, A., Dragoš, A., Resnik Planinc, T., Škof, U., 2008. Učni načrt. Gimnazija. Geografija. Splošna, klasična, ekonomska gimnazija. Ljubljana, Ministrstvo za šolstvo in šport, Zavod RS za šolstvo, 60 str.

Popit, S., 2011. Geografija 1. Učbenik za 1. letnik gimnazij. 1. izd. Ljubljana, DZS, 190 str.

Račič, J., Tomšič, Ž., 2005. Geografija 7. Učbenik za geografijo v sedmem razredu osnovne šole. 1. izd. Ljubljana, Mladinska knjiga, 95 str.

Račič, J., Večerič, D., 2009. Geografija 9. Učbenik za geografijo v devetem razredu osnovne šole. 1. izd. Ljubljana, Mladinska knjiga, 91 str. 
Resnik Planinc, T., Bahar, I., Račič, J., 2012. Geografija 8. Učbenik za geografijo v osmem razredu osnovne šole. 1. izd. Ljubljana, Mladinska knjiga, 84 str.

Senegačnik, J., 2007. Demografija Slovenije v šolskih geografskih učbenikih. V: Malačič, J., Gams, M. (ur.). Slovenija pred demografskimi izzivi 21. stoletja. Zbornik 10. mednarodne multikonference Informacijska družba. Ljubljana, Inštitut Jožef Stefan, str. 114-116.

Senegačnik, J., 2008. Slovensko zamejstvo v šolskih geografskih učbenikih. V: Malačič, J., Gams, M. (ur.). Slovenija pred demografskimi izzivi 21. stoletja. Zbornik 11. mednarodne multikonference Informacijska družba. Ljubljana, Inštitut Jožef Stefan, str. 94-96.

Senegačnik, J., 2011. Slovenija 2. Geografija za 4. letnik gimnazij. 1. izd. Ljubljana, Modrijan, 134 str.

Senegačnik, J., 2012a. European traditional national minorities in Slovenian geography textbooks compared with textbooks from other European countries. IARTEM Journal, 5,1 , str. 31-32.

Senegačnik, J., 2012b. Geografija Slovenije. Učbenik za 9. razred osnovne šole. 1. izd. Ljubljana, Modrijan, 143 str.

Senegačnik, J., 2012c. Svet. Geografija za 2. letnik gimnazij. 9. izd. Ljubljana, Modrijan, $136 \mathrm{str}$.

Senegačnik, J., 2013a. Geografija Evrope in Azije. Učbenik za 7. razred osnovne šole.

2. izd. Ljubljana, Modrijan, 130 str.

Senegačnik, J., 2013b. Moja prva geografija. Učbenik za 6. razred osnovne šole. 7. izd. Ljubljana, Modrijan, 70 str.

Senegačnik, J., 2013c. Slovenija 1. Geografija za 3. letnik gimnazij. 3. izd. Ljubljana, Modrijan, 120 str.

Senegačnik, J., Drobnjak, B., 2013. Obča geografija za 1. letnik gimnazij. 10. izd. Ljubljana, Modrijan, 192 str.

Senegačnik, J., Lipovšek, I., Pak, M., 2009. Evropa. Geografija za 2. in 3. letnik gimnazij. 4. izd. Ljubljana, Modrijan, 168 str.

Verdev, H., 2008. Raziskujem Zemljo 6. Učbenik za geografijo v šestem razredu osnovne šole. 1. izd. Ljubljana, Rokus Klett, 56 str.

Verdev, H., 2010a. Raziskujem Stari svet 7. Učbenik za geografijo v sedmem razredu osnovne šole. 1. izd. Ljubljana, Rokus Klett, 103 str.

Verdev, H., 2010b. Raziskujem Novi svet 8. Učbenik za geografijo v osmem razredu osnovne šole. 1. izd. Ljubljana, Rokus Klett, 87 str.

Verdev, H., 2011. Raziskujem Slovenijo 9. Učbenik za geografijo v 9. razredu osnovne šole. 1. izd. Ljubljana, Rokus Klett, 95 str. 


\section{MIGRATIONS IN SLOVENIAN GEOGRAPHY TEXTBOOKS}

\section{Summary}

Migrations are a phenomenon which is included in almost all geographical textbooks for different levels of education in Slovenia. We can distinguish between three groups of textbooks. The first group are the textbooks for the compulsory school (lower level of secondary education) from the sixth to the ninth grade. In these grades, the pupils acquire basic knowledge on migrations using the inductive approach. The complexity of treatment and the amount of information is growing, depending on the age level. Most attention to migrations is devoted in the chapters which treat population. This is true for the regional geographies of Europe, ex-European continents and Slovenia.

The second category are the textbooks for the grammar school program (upper level of secondary education). The first year of this program is devoted to the general geography. The second, third and fourth year are devoted to the more problem-oriented regional geography. The way of acquiring knowledge about migrations in these textbooks is deductive. Migrations are the most detailed explained in the general geography textbooks in the content sections of the population. Detailed explanations of migrations are in the chapters on America and Australia because there was a massive immigration on these continents in history. The third group are the textbooks for vocational and technical programs which deal with migrations to a lesser extent and also, approaches differ greatly. 